\title{
THE TRANSFORMATION OF ENGLISH AS A GLOBAL LANGUAGE IN THE WORLD
}

\author{
Salmon Pandarangga
}

\section{Email: spsumba@gmail.com}

Stie Kriswina Sumba

Alamat Korespondensi: Jalan Suprapto 35 Waingapu - NTT, 87113

\begin{abstract}
It is argued that English as a global language has some advantages to people around the world. One of the advantages is that English language is used as a tool of communication, empowerment and unification of people in the global community. In other words, English plays a very important role to unite all the people around the globe regardless their nationalities, cultural backgrounds, or races. However, for some scholars, English is seen as a potential threat to linguistic diversity in the world (Florey, 2010; Graddol, 1997; Tsuda, 2008; Phillipson, 2008). These scholars strongly believed that the dominant and powerful of English use in the global community has destroyed and killed most of the languages in the world. Some of the languages, as Florey claimed, become death languages. These scholars thus believed that English is responsible for the loss and death of thousands of minority native languages around the world. Instead of debating and taking side, it is argued that non-native speakers will use their own English teaching materials with their own context culturally, English will share the role as a global language with other languages e.g. Arabic, Spanish, Bahasa Indonesia, Mandarin, and there will be more new and various of English (es) forms around the world.
\end{abstract}

Keywords: a global language, English, communication, linguistic diversity, transformation

\section{INTRODUCTION}

English, like other languages around world, is an ordinary and common language. Historically, the language was spoken by a small number of people in a small region of northern Europe, which is known today as a Great Britain. It was even predicted that the language would have no possibility to spread out from the island. It is the Richard Mulcaster, the headmaster of Merchant Taylor's School and one of the strongest supporters of English, who pointed out in his writing in 1582: "Our English tongue is of small reach- it stretcheth no further than this island of ours - nay, not there over all." (Crystal, 2000, p.5). In short, English would stay on the island forever.

However, Richards' forecast was not true as the expansion of English is fast reaching every corner of the world. In fact, this language is used widely whether as a first language, second language, foreign language or even international language among many languages around the world. Crystal (2003, p.5) claimed that more than a billion people worldwide speak, learn, taught and use English as a first, second, foreign and international language in more than a hundred countries such as Russia, Germany, China, Indonesia, Thailand and other countries.

Unlike other languages, some scholars such as Ammon (2001, p.345); Baker (2006, p.12); Gradol (1997, p.3) strongly believed that English is an "exceptional" language since it is highly preferred and chosen for education, occupation and communication. In education, for example, almost all countries around the 
world choose English as one of the compulsory subjects in schools. Some countries start teaching English since elementary schools while others junior high schools. As one of the compulsory subjects, students are required to study English in order to pass their junior or senior high schools. English also becomes one of the compulsory subjects in university entrance examinations.

Moreover, most of companies around the world highly require their workers to know and understand English. One of the companies' requirements in advertisement in hiring new workers is the ability to speak or write in English. Graddol (1997, p.3) also believed that English is used as a gateway in exchange information or transaction of business in the world. Similarly, Hammer (2007, p.13) strongly believed that English is now commonly used as a language for economic activities globally.

Furthermore, English is used as a language to communicate across national borders. Using English to communicate may also help people to know, understand and respect each other particularly those who have different backgrounds such as languages, cultures, lifestyles and etc. One of the famous people, Martin Luther King, Jr, stated, "People don't get along because they fear each other. People fear each other because they do not know each other. They don't know each other because they have not properly communicated each other" (King, M., n.d. cited in Adler \& Rodman, 1991, p. 12). Furthermore, Seidlhofer (2005, p.339) stated that English as a world language, international language or global language communication may highly effectively avoid misunderstanding and misinterpretation among individuals.

However, the issue as to whether English is a global language has triggered thoughtful, controversial and prolonged arguments and has even lead to tension among the authors and scholars around the globe. The arguments have split up the authors and scholars into two main different perspectives. Some authors have labeled English with negative terms such as; a lingua frankensteinia, an English monster, a linguicide (Phillipson, 2008, p.250); a linguistic imperialism (Phillipson, 1992 cited in Phan, 2008, p. 72) a lingua tyrannosaura
(Swales, 1996 cited in Phillipson, 2008, p. 251) and other negative terms. For these authors use these negative terms to give a clear picture of how English as global language has become a nightmare around the world particularly linguistic diversity. These authors, for example, strongly believed that English has already killed many local languages in the world.

Tsuda (2008, p. 47) labeled the English language as English hegemony. According to Tsuda English hegemony is a situation where the dominance of English threatens and kills other languages especially the weaker and smaller ones around the world. In fact, some of the languages become endangered and death languages in some part of the world. Nettle and Romaine (2000) as cited in Tsuda (p.49) noted that almost 6,000 to 7,000 languages worldwide had disappeared over the past 500 years. They claimed the number of language disappear is increasing faster these days. In other words, English is getting popular and therefore attract more people worldwide to use and speak English and sadly abandon their native language(s).

Moreover, as Tsuda further continued, the dominance of English over other (indigenous) languages may and will cause and create "discrimination, injustice and inequalities among those who speak it and those don't and cannot write or speak English" (p. 47). One of the discriminations, for example, is that people are required to have very good English skills when they apply for jobs. In other words, it discriminated against those who want to apply for jobs but cannot write or speak English. Another example, as continued by Tsuda, is that almost $86 \%$ people around the world learn English as a foreign language (p.54). These people are likely to have position that is more prestigious when they have more competence in English than their native languages. In facts, English is imposed to become one of the compulsory subjects in schools globally. Moreover, it seems that some countries continuously support and encourage their people to learn English and, to some extent, discourage them from learning the locals.

In contrast, English is seen as a connective instrument that link people worldwide. This language unites and connects all the people around the world regardless of 
their cultures, nationalities, beliefs, and countries. Crystal (2003, p.5) strongly believed that English turns and makes the big world into a small village. In short, English as a global language has united and connected all the people worldwide in term of communication. For example, people in India, Senegal, Portugal and Spain can share cultural understandings such as norms, values and beliefs through English as a medium of communication. In this ways, it can at least decrease and minimize cultural misunderstandings among people around the world.

In addition, English is seen as a bridge to communicate and solve differences e.g. politics and conflicts across the countries globally (Garcia and Otheguy, 1989 as cited in Phan, 2008, p.3). The differences and conflicts between or among countries in one region may sometimes possibly lead to wars. However, these conflicts are mostly avoidable with mediation and negotiation through English as a medium of communication.

It seems obvious and clear that both sides make their claim to be the right one while the others are wrong. Scholars and their faithful followers from proponent and opponent sides tend to argue and attack each other. It is not very unlikely that these situations would lead people to take side and support one of them. Moreover, the worst things, these debates may lead to endless circling arguments without any significant solutions to solve these issues.

It is therefore, instead of debating whether English as a global language has either negative or positive side, this essay will argue that English will still stay remain as a global language but there will be major transformations including the use of English teaching in foreign countries, a less dominant position globally and a further diversity of English (es) in the future. This article will deal with these three areas beginning with some foreign countries will use their own English teaching materials with their own context culturally, English will share the role as a global language with other languages e.g. Arabic, Spanish, Bahasa Indonesia, Mandarin, and there will be more new and various of English (es) forms around the world.

\section{The diversity use of English teaching materials globally}

First of all, the use of English teaching materials in foreign countries will be likely to be different from countries where English is the native language. Some theorists, such as Graddol (1997, p.57), claimed that some nonnative countries are likely to create and develop their own English resources such as teaching methods, curricula and materials. The English teaching and learning resources are designed and developed in line with the English language rules and knowledge but based on local culture background. In other words, as Graddol further claimed, authors of non-native speakers are strongly believed to have the ability and capability to design and develop the English materials because they know and best understand the social context of their own countries (p.58).

In order to support Graddol's claim, the argument being forward here is similar to Phan (2008, p.95) that English teaching learning resources designed and developed by the English native-teachers or experts may be highly likely appropriate for native English countries but not in non-native context. For instance, the teaching and learning of words for foods such as hamburger, hotdog, and pizza may be more appropriate for schools in western countries e.g. British, Canada or Australia but not in Indonesia. These kinds of foods are not typically found or consumed by Indonesian people. Similarly, teaching English about local and traditional transportation such as becak, bemo, andong and etc is culturally more appropriate in Indonesia than in Australia. Hence, it is important to consider the social and cultural local context of the non-native countries where English teaching is taught. Interestingly, following from Kirkpatrick's point of view (1997) as cited in Wong and Kam (2004, p.463) argued with a clear and insightful example that:

"those in East Asia, learning English in order to speak to each other (e.g. Vietnamese to Thais or Indonesians) do not need culturally Western language materials. What they do need is some knowledge of the culture of the people they are dealing with and they need to be aware of their own cultural norms. The culture of the person they are speaking to is more important than any cultures associated with native speakers of English. 
These learners need English language materials that contrast and explain regional cultures".

When Kirkpatrick's argument is analyzed, it can be seen that when people learn or teach English, they do not necessarily to be like the native-speakers of English culturally. The most important thing that the purpose of teaching and learning English is to connect, communicate and share with other people worldwide regardless of whether they use English as their native language or nonnative language.

To some circumstances, the idea of creating culturally locally English teaching materials by those who use English as nonnative language is likely to have benefited for the non-native learners of English. However, it is believed that developing and creating English teaching materials linked to the local cultures is not sufficient. According to Strevens (1992, p. 39-41) teaching English in non-native countries still need the presence or intervention of English native speakers to design the language in terms of language design. The native speakers, as Strevens further states, are still needed to evaluate and assess whether the approach and methodology are properly and systematically designed. It is also believed that the native speakers can guide and assist their counterparts in designing and preparing the English materials.

It is therefore Thao (1991) as cited in Kam (2004, p.465) proposed a sensible solution that it is necessary to consider the collaboration between native-speakers who design qualified English textbooks and nonnative speakers who understand the local cultural contexts. It is strongly believed that this kind of collaboration help both sides to improve, increase and develop the quality of English teaching and learning as well as textbooks globally. In fact, this collaboration has been done and implemented around the globe such as China, India, Africa, Korea and other countries. For example, there are some big cities in China e.g. Shanghai and Guangzhou have already adopted and adapted English textbooks into Chinese's culture published by native publishers' e.g. Oxford University Press in order to meet or suit the local students' learning needs (Zhang, 2004, p.150). In other words, the textbooks are written, develop and published in English but in local context-based.

Similarly, some English countries such as United Stated, United Kingdom, Canada and Australia establish English institutions in most of the non-English countries in the world. For example, Australia establishes English institution in Indonesia e.g. IALF, Indonesia Australia Language Foundation (http://www.ialf.edu/). The purposes of this institution are to train, improve and increase English language skills for learners and also design language teaching methodology for English teachers in Indonesia. One of the programs is that trainers or teachers, mostly native speakers, visit all around Indonesia to train the English teachers. Therefore, even though the non-native speakers seem to be able to create and develop their own English materials, they still need collaboration and assistance from the native speakers.

\section{The less dominant of English as a global language}

Secondly, English as a global language is likely to be less dominant in the world. Graddol (1997, p.8) noted that some major languages such as Spanish, Arabic, Mandarin, and Russian are rising rapidly and becoming more preferred. In order to support his claim, he points out that Mandarin as a regional language becomes more important as a lingua franca of Greater China for economic communication in the regions of Hong Kong, Shanghai and overseas Chinese in the SouthEast Asia e.g. Singapore, Indonesia, Malaysia. Similarly, the domination of other major languages can also be seen in some regions e.g. the position of Spanish in South America, Russian in central and north Asia and also Arabic in middle-east and some Islamic countries. One of the examples is that some Islamic countries use Arabic language to read and learn the holy book Koran.

Also, English will not dominate some international medias such as CNN, BBC, MTV and etc. These medias are not only broadcast news in English but also some other major dominant languages such as Spain, Arabic, Mandarin and etc. In other words, it is believed that these international medias are broadcast with different languages in order to attract a large number of viewers in the world (McPhail, 2010, p.305). These medias, as 
McPhail further argued, realize and believe that to get huge market shares and more money, these medias need and have to reach the local viewers with the language they use. In short, English seems to be less needed.

Consequently, as English is likely to be less dominant in the future, it cannot be accused as the main or direct cause of endangered and dead of small minority languages around the world (Tsuda, 2008, p.49). Some of the major languages such as Chinese, Arabic, Bahasa Indonesia and Spanish also should take responsibility to the endangered or dead of minority languages in their countries. These major languages continuously threaten the existence of some of the minority languages in the world. Harmer (2007, p.16) gives example how some Andean languages are continuously threatened by Spanish. Similarly, Florey (2010, p.4) claimed that some local minority languages in Indonesia are critically endangered and some of them become death languages because of Bahasa Indonesia.

Thus, it can be concluded that English as a global language is less dominant because some major languages e.g. China, Spain, and Mandarin are rapidly expanded in some regions. In other words, these major languages are also likely to challenge English as a global language.

\section{The new and diversity of English form (s)}

Thirdly, English will be diverse whenever it comes to new environment. It is strongly argued that the adoption of English on local forms appears to produce more variety of English or it is called as Englishes (Graddol, 1997, p.12-13). The term "Englishes" refers to acculturation and variation of English and local language in which it needs to be recognized as "functional diversity" (Kachru, 1985) as cited in Tsuda (2008, p.48). In other words, the development, growth and maturation of a number of English varieties worldwide e.g. Singapore, Africa, India (Bamgbose, 1995; Crystal, 2000; Kam \& Wong, 2004) may reflect the diversity of English. Crystal (2000, p.6) stated:

"the cultural domains which are likely to generate new vocabulary when English comes to be used in such places such as West Africa, Singapore, India, or South Africa, and peakers find themselves adapting the language to meet their communicative needs-not just native speakers, of course, but those who learn it as a second or foreign language as well".

He went on to say: "to have learned a language is immediately to have rights in it. You may add to it, modify it, play with it, create in it, (and) ignore bits of it, as you will. And it is just as likely that the future course of English is going to be influenced by those who speak it as a second or foreign language as by those who speak it as a mother-tongue".

In other words, the speakers and cultural context of the new environments will mainly influence the diversity of English. Similarly, Mesthrie (2008, p. 28) believed that there is an increasing use of Englishes by nonnative speakers with different varieties in cultural context not traditionally associated the original language of native speakers. Moreover, English as dynamic and flexible language can easily adapt with new places, say, it can generate new vocabulary. For example, South African Sunday Times "Diplomatic Indabas only rarely produce..." indaba is a word in the Nguni tribal language which originally means, a tribal conference, but it has been extended to mean any conference between political groups (Crystal, 2000, p.6). Similarly, in Nigeria, the influence of English on Nigerian language can be traced in a number of loanwords such as doti (dirty), loya (lawyer), telo (taylor), palo (parlour) and others (Bamgbose, 1995, p.9).

English also adapt or adopt other languages into English. For example, Aboriginal words such as boomerang, dingo, kangaroo, koala and other words are now common in English language (Arthur, 1996, p.5). Likewise, some Indian words such as squash, tomahawk, totem and other Indian words are also common in English (Leith, 2007, p.197). It can be seen that English is not only adapted or adopted into local languages but also adapt or adopt other foreign languages into English.

Using the work of Crystal (2000), it can be shown that the future of English will not be simply to be more like the version used widely of British English or American English. Therefore, despite the fact that English originally was from British or America, it seems that English varieties will be increasing in which the varieties are likely to be 
difference from the original of English British or American. Moreover, the speakers of English varieties seem to outnumber the native speakers.

\section{CONCLUSION}

Finally, English as a global language has triggered some major transformations. These transformations have led to some changes. It is argued that English will transformed itself when it comes to new environment. English also will face some challenges from other languages e.g. Mandarin, Arabic, Spain. The use and the speakers of English will also significantly different from the original one. In fact, there will be many English varieties worldwide. Moreover, those who speak the English varieties may even outnumber the nativespeakers e.g. British English. In the future, it is believed that English will still as a global language but with different perspective and varieties of English. Thus, people should not see English as a language that will bring disadvantages but as a language that will change. People should see this as an opportunity to improve their life. Another thing, people should also use speak and promote, like English, their local languages. In this way, it does not only preserve these local languages around the world but also inherit these languages for the next generation in the future.

\section{REFERENCE}

Adler, R., \& Rodman, G. (1991). Understanding human communication (4thed.). Fort worth: Holt, Rinehart, and Winston.

Ammon, U. (2001). The Dominance of English as a Language of Science: Effects on Other Languages and Language Communities. Berlin: Walter de Gruyter \& Co.

Arthur, J.M. (1996). Aboriginal English: A Cultural Study. Melbourne: Oxford University Press.

Baker, C. (2006). Foundations of Bilingual Education and Bilingualism (4th). United States of America: Archetype-IT Ltd.

Bamgbose, A. (1995). English in the Nigerian Environment. In Bamgbose, Banjo \& Thomas (Ed). New Englishes: A West African Perspective Nigeria: Intec Printers Ltd.

Crystal, David. (2000, January). The future of English as a world language. Concord, 4-7. Retrieved from http://www.davidcrystal.com/DC articles/English22.pdf

Crystal, David. (2003). English as a global language (2nd). Retrieved from: http://books.google.com.au/books?id=d6jPAKxTHRYC\&printsec.

Dewey, M. (2007). English as a Lingua Franca and Globalization: an Interconnected Perspective. International Journal of Applied Linguistics. Vol. 17. No. 3.

Florey, Margareth. (2010). Endangered Languages of Austronesia. Retrieved from: http://books.google.com.au/books?id=eNF4FxSd-LgC\&pg

Graddol, D. (1997). The future of English. Retrieved from http://www.british council.org/English/pdf/future.pdf

Harmer, Jeremy. (2007). The practice of English language teaching. Cambridge, UK: Pearson Longman. 
I.A.L.F. Welcome to IALF: Education for Development. Retrieved from: http://www.ialf.edu/

Kam, W.H. (2004). RELC'S Role in ELT in Southeast Asia (1968 to 2002): Mediating Between the Centre and the Periphery. In Kam, W. Ho \& Wong, Ruth. (Ed.) English Language Teaching in East Asia Today: Changing Policies and Practices $\left(2^{\text {nd }}\right)$. Singapore: Times Graphics Pte Ltd.

Kam, W. Ho \& Wong, Ruth. (2004). The Future of English Language Teaching in East Asia. In Kam, W. Ho \& Wong, Ruth. (Ed.) English Language Teaching in East Asia Today: Changing Policies and Practices (2nd). Singapore: Times Graphics Pte Ltd.

Leith, D. (2007). English-Colonial to Postcolonial. In Graddol,D, Leith,D, Swann,J, Rhys, M, Gillen, J. (Ed.) Changing English. New York: Routledge.

McPhail, L. Thomas. (2010). Global Communication: Theories, Stakeholders and Trends. Retrieved from: http://books.google.com/books?id=heEppDtfkNoC\&pg.

Mesthrie, R. (2008). English Circling the Globe: A Commentary on a Seminal ET Article by Braj Kachru. English Today 93, Vol.24, No.1. DOI: 10.1017/S0266078408000072.

Phan, Le Ha. (2008). Teaching English as an International Language: Identity, Resistance and Negotiation. Clevedon, Buffalo: N.Y Multilingual Matters, New Perspectives on Language and Education eBook ISBN: 9781847690500.

Phillipson, R. A. (2008). Lingua franca or lingua frankensteinia? English in European integration and globalisation. World Englishes, 27(2), 250 - 267. Doi: 10.1111/j.1467-971X.2008.00555.x

Seidlhofer, B. (2005). Key concepts in ELT. English as a lingua franca. ELT Journal, 59(4), 339 - 341 doi:10.1093/elt/cci064

Swales, J. \& Feak C. (2004). Academic Writing for Graduate Students: Essential Tasks and Skills. University of Michigan Press: Ann Arbor.

Strevens, Peter (1992). English as an International Language: Direction in the 1990s $\left(2^{\text {nd }}\right)$ in Kachru, B. (Ed.). The Other Tongue: English Across cultures. Retrieved from: http://books.google.com.au/books?id=DV4pddGfYSIC\&pg.

Tsuda,Y. (2008). English Hegemony and English Divide. China Media Research, 4(1), 47-55.

Zhang, L. (2004). Extending the Reach of Middle School EFL Teachers in the People's Republic of China. In Kam, W. Ho \& Wong, Ruth. (Ed.) English Language Teaching in East Asia Today: Changing Policies and Practices (2 $\left.{ }^{\text {nd }}\right)$. Singapore: Times Graphics Pte Ltd. 